\title{
ПОДАТКОВІ ЗАПИТИ ЯК СПОСІБ ВИКОНАННЯ ФУНКЦІЙ ДЕРЖАВНОЇ ПОДАТКОВОЇ СЛУЖБИ УКРАЇНИ
}

\begin{abstract}
Метою наукової статті $є$ аналіз сучасного стану законодавчого регулювання спрямування уповноваженими особами Державної податкової служби України податкових запитів до платників податків, виявлення основних недоліків та проблем нормативного закріплення порядку подання податкових запитів на отримання інформації. Акцентовано увагу, що дотримання уповноваженими особами Державної податкової служби України вимог законодавства $\epsilon$ запорукою виконання функції контролю Державної податкової служби України. Визначено основні напрями вдосконалення чинної законодавчої бази з погляду регулювання основних принципів та вимог щодо податкових запитів, зосереджено увагу на деяких особливостях належного оформлення податкових запитів, проаналізовано основні недоліки чинного законодавства та шляхи їх усунення. Зроблено висновки щодо необхідності вдосконалення сучасної законодавчої бази України. Досліджено сутність та правову природу податкових запитів, проведено аналіз слабких місць законодавчої системи України з погляду регулювання та спрямування податкових запитів до платників податків. На основі аналізу чинного законодавства України зроблено висновки про необхідність вдосконалення низки нормативно-правових актів. У науковій статті зазначено, що непоодинокими $\epsilon$ випадки, коли недосконалість та неконкретизованість направлення Державною податковою службою Украӥни запитів платникам податків $\epsilon$ наслідком нереалізації функції контролю Державної податкової служби України. Недотримання базових вимог до оформлення податкових запитів із боку уповноважених працівників Державної податкової служби України часто слугують приводом для відмови в наданні запитуваної інформації, що $\epsilon$ негативним явищем. Запропоновано вирішення наявних проблем щодо направлення податкових запитів шляхом оптимізації та доповнення окремих нормативно-правових актів відповідними нормами права. Тому в сучасних умовах необхідно оптимізувати податкове законодавство, щоб воно було ефективним та впроваджувалося Державною податковою службою України.
\end{abstract}

Ключові слова: Державна податкова служба України, податкові запити, податкове законодавство, контролюючі органи, платники податків, державна служба.
Денисова А. В., Слаблюк Н. С.

Denisova A. V., Slabliuk N. S. Tax requests as a way to perform functions State Tax Service of Ukraine

The purpose of this article is to analyze the current state of legislative regulation of the direction of authorized persons of the State Tax Service of Ukraine tax requests to taxpayers, identify the main shortcomings and problems of regulatory consolidation of the direction of tax requests to obtain information. The main directions of improving the current legal framework in terms of regulation of the basic principles and requirements for tax inquiries are identified, attention is focused on some features of the proper design of tax inquiries, the main shortcomings of current legislation are analyzed and ways to eliminate them are identified. Conclusions are made on the need to improve the modern legislative framework of Ukraine.

The purpose of this article is to present the current rules of law governing the sending of authorized requests of the State Tax Service of Ukraine to taxpayers, and indicate the mechanisms for its improvement in connection with the specifics of the State Tax Service of Ukraine. The essence and legal nature of tax requests are studied. The analysis of weaknesses of the legislative system of Ukraine from the point of view of regulation and direction of tax inquiries to taxpayers is carried out. Based on the analysis of the current legislation of Ukraine, conclusions are made about the need to improve regulations.

The author notes that the direction of modernization of legislation is a positive phenomenon, as it encourages the legislator to make changes and reforms of the State Tax Service of Ukraine in general, changes in legislation governing the activities of authorized employees of the State Tax Service of Ukraine - affects the whole process, interaction with society and other public authorities establish guarantees of observance of the rights and interests of taxpayers.

Constant changes in tax legislation, although aimed at improving it, do not always work in favor of taxpayers. All this is due to sufficient gaps in legislation and inefficiency of innovation. Therefore, in modern conditions, it is necessary to optimize the tax legislation so that it was effective and implemented by the State Tax Service of Ukraine.

Key words: State Tax Service of Ukraine, tax inquiries, tax legislation, controlling bodies, taxpayers, civil service.

(ㄱ Денисова А. В., Слаблюк Н. С., 2020 
Постановка проблеми та іï актуальність. Податкові запити відіграють важливу роль у реалізації функції контролю Державної податкової служби України. 3 метою реалізації поставлених перед Державною податковою службою України завдань уповноважені особи цього органу направляють податкові запити для отримання від платників податків інформації (пояснення, копії документів тощо). Протягом тривалого часу спостерігається недосконала реалізація досягнення мети направлення податкових запитів. Через недодержання формальностей в оформленні податкових запитів уповноваженими працівниками Державної податкової служби України непоодинокими $\epsilon$ випадки ненадання відповідей на такі податкові запити з боку платників податків. Водночас звільнення від надання інформації на податкові запити, у разі їх неправильного оформлення, урегульовано нормами чинного законодавства. Натепер наявна проблема щодо чітких вимог до оформлення уповноваженими працівниками Державної податкової служби України податкових запитів. Потребує вдосконалення затвердження переліку необхідних документів, які направляються платникам податків разом із податковими запитами. Актуалізація норм чинного законодавства в частині вимог до оформлення податкових запитів дасть можливість більш ефективно використовувати їх сутність та призначення.

Аналіз останніх досліджень і публікацій. Питання щодо правової природи та порядку направлення податкових запитів розглядалось такими українськими вченими, як: О.М. Василика, Л.Ю. Касьяненко, П.М. Дозорець, С.С. Мороз, Н.В. Гусак та інші. Проте проблема дослідження реалізації функції контролю Державної податкової служби України через направлення податкових запитів більш ретельно натепер не досліджувалась.

Метою статті $\epsilon$ дослідження ефективності сучасного регулювання направлення уповноваженими працівниками Державної податкової служби України податкових запитів, виявлення основних недоліків законодавства та розгляд перспектив ухвалення змін до нормативно-правових актів і метою врегулювання конкретних наявних недоліків, які натепер не відповідають вимогам чинного законодавства.

Виклад основного матеріалу. Сьогодні Державна податкова служба України відіграє важливу роль у реалізації функції контролю з боку держави, яка полягає в тому, що за допомо- гою наданих Державній податковій службі України повноважень можна перевірити діяльність платників податків і метою дослідження дотримання ними законності у своїй діяльності та додержання податкової дисципліни, порушення якої передбачає юридичну відповідальність. Сутність, основні завдання та напрям розвитку Державної податкової служби України з найбільшою повнотою об' єктивно виявляються в іiі функціях, тобто основних напрямах діяльності, завданнях, які вона ставить перед собою, формах і методах, за допомогою яких ця діяльність здійснюється. На виконання покладених на Державну податкову службу України завдань та функцій у нормативно-правових актах закріплені відповідні права посадових осіб, проте натепер таке закріплення потребує гармонізації й удосконалення.

Однією з найважливіших функцій Державної податкової служби України $\epsilon$ функція контролю, основною метою якої $\epsilon$ підвищення ефективності діяльності шляхом аналізу, перевірки та зіставлення наявної інформації щодо діяльності платників податків. За допомогою контролю забезпечується злагоджена та чітка робота органів державної влади загалом, сумлінне та якісне виконання посадовими особами, усіма державними службовцями наданих їм прав, сумлінне ставлення до виконання своїх обов'язків для забезпечення добробуту населення. Варто зазначити, що функція контролю Державної податкової служби України $є$ різновидом державного контролю загалом, оскільки їй притаманні всі ознаки останнього: вона $\epsilon$ складовою частиною державної діяльності, складовою частиною соціального контролю, має спеціально уповноважених державою суб'єктів здійснення, економічний характер, постійну основу, державно-владну природу, активний характер тощо. Функція контролю здійснюється у сфері фінансової діяльності, а точніше, її складової частини - оподаткування (що визначає ії зміст, завдання, цілі тощо), реалізується спеціально уповноваженим органом державної влади - Державною податковою службою України [6, с. 117].

Для підвищення податкової дисципліни треба ґрунтовно вивчити функцію контролю Державної податкової служби України. Варто звернути увагу на те, що натепер це питання на відповідних науковому, методичному та методологічному рівнях не обґрунтовано. Функція контролю Державної податкової служби України відіграє важливу роль у суспільстві, $\epsilon$ основною функцією, оскільки ії виконанням Державна подат- 
кова служба України встановлює достовірність даних про повноту, своєчасність та законність господарських операцій платників податків, а також виявляє порушення чинного законодавства. Реалізація функції контролю $є$ одним з основних завдань Державної податкової служби України.

Слушною щодо цього $є$ думка Н.Б. Гусака, який відзначав, що держава $\epsilon$ одним із головних суб'єктів функції контролю в суспільстві. Це випливає з того, що держава має можливості та реальні повноваження для впливу на суспільство, під час здійснення якого здійснюється контроль. Саме він відіграє роль інтегрувального засобу перевірки загальної спрямованості державної діяльності та водночас перевірки досягнення кінцевого результату управлінської діяльності [5, с. 320].

Що стосується нормативного закріплення реалізації функції контролю Державної податкової служби України, то варто зазначити, що відповідно до п. п. 20.1.2 Податкового кодексу України, для здійснення функцій, визначених законом, Державна податкова служба України має право отримувати безоплатно від платників податків, зокрема і благодійних та інших неприбуткових організацій, усіх форм власності в порядку, визначеному законодавством, довідки, копії документів, засвідчені підписом платника або його посадовою особою та скріплені печаткою (за наявності), про фінансово-господарську діяльність, отримані доходи, видатки платників податків, іншу інформацію, пов'язану з обчисленням та сплатою податків, зборів, платежів, про дотримання вимог законодавства, здійснення контролю за яким покладено на контролюючі органи, а також фінансову і статистичну звітність у порядку та на підставах, визначених законом [2].

Згідно з п. 4 ч. 4 Положення «Про Державну податкову службу України», затвердженого постановою Кабінету Міністрів України № 277 від 6 березня 2019 р. (далі - Положення), Державна податкова служба України здійснює контроль за дотриманням вимог податкового законодавства, законодавства щодо адміністрування єдиного внеску та законодавства з інших питань. П. п. 7, 13 Положення окремо визначено право Державної податкової служби України запитувати та вивчати під час проведення перевірок первинні документи, що використовуються в бухгалтерському обліку, регістри, фінансову, статистичну й іншу звітність, пов'язану з обчисленням і сплатою податків, зборів, платежів, виконанням вимог законодавства, контроль за дотриманням якого покладено на Державну податкову службу України, а також надсилати платникам податків (платникам єдиного внеску) у межах повноважень, передбачених законом, у разі виявлення порушень вимог податкового законодавства чи законодавства з інших питань, контроль за дотриманням якого покладено на Державну податкову службу України, письмові запити щодо надання засвідчених належним чином копій документів [3].

Із тлумачення вищевказаних норм Податкового кодексу України та Положення можна зробити висновки, що в Державної податкової служби України виникає нормативно врегульоване право на відправлення письмових запитів платникам податків. Закріплення в різних нормативно-правових актах (Кодекс та підзаконний нормативно-правовий акт) права Державної податкової служби реалізувати функцію контролю $є$ позитивним явищем у розрізі нормативного закріплення реалізації повноважень органом державної влади.

Водночас недосконалість та неконкретизованість направлення Державною податковою службою України запитів платникам податків $є$ проблемою реалізації функції контролю. Так, відповідно до пп. 73.3 Податкового кодексу України, органи контролю мають право звернутися до платників податків та інших суб'єктів інформаційних відносин із письмовим запитом про подання інформації (вичерпний перелік та підстави надання якої встановлено законом), необхідної для виконання покладених на контролюючі органи функцій, завдань, її документального підтвердження. Такий запит підписується керівником (його заступником або уповноваженою особою) контролюючого органу і повинен містити підстави для надіслання запиту відповідно до вищевказаного пункту, із зазначенням інформації, яка це підтверджує.

У результаті проведеного аналізу вищевказаної норми Податкового кодексу України можна зробити висновок, що разом із направленням платникам податків податкових запитів уповноваженим особам Державної податкової служби України необхідно також додати до таких запитів документальне підтвердження із зазначенням інформації, яка є підставою для направлення таких запитів. Частими є випадки, коли уповноважені особи Державної податкової служби України під час направлення ними податкових запитів не надають документального підтвердження підстав 
для направлення таких запитів. Вказане вище $\epsilon$ фактом порушення вимог до оформлення податкових запитів, що $є$ підставою для ненадання платниками податків відповіді на запит Державної податкової служби України.

Відповідно до пп. 73.3 Податкового кодексу України, якщо запит складено з порушенням вимог, визначених абз. 1-5 цього пункту, платник податків звільняється від обов'язку надавати відповідь на такий запит.

Про контроль за правильністю та повнотою податкових запитів згадується в п. 11 постанови Кабінету Міністрів України № 1245 від 27 грудня 2010 р. «Про затвердження Порядку періодичного подання інформації органам державної податкової служби та отримання інформації зазначеними органами за письмовим запитом», де зазначено, що перед тим, як направити запит, орган державної податкової служби перевіряє наявність законодавчих підстав для отримання податкової інформації [4]. Отже, можна зробити висновок, що на законодавчому рівні закріплені вимоги щодо оформлення податкових запитів, наслідки їх недотримання.

Відповідно до ст. 19 Конституції України, органи державної влади й органи місцевого самоврядування, їх посадові особи зобов'язані діяти лише на підставі, у межах повноважень і способом, що передбачені Конституцією та законами України. Правовий порядок в Україні ґрунтується на засадах, відповідно до яких ніхто не може бути примушений робити те, що не передбачено законодавством [1]. Отже, на органи державної влади поширюється спеціально-дозвільний тип правового регулювання - «заборонено все, що прямо не дозволено законом», тобто Державній податковій службі України дозволено лише те, що прямо передбачено законом.

Недотримання уповноваженими особами Державної податкової служби України вимог до оформлення податкових запитів призводить до нівелювання їхньої правової сутності, а також неотримання органом контролю запитуваної інформації від платників податків.

Можливим шляхом вирішення даної проблеми $\epsilon$ вдосконалення та конкретизація пп. 73.3 Податкового кодексу України, а саме: доповнення його нормою, відповідно до якої в разі направлення податкового запиту орган контролю зобов'язаний додати до нього документальне підтвердження підстав для такого запиту. Це можуть бути копія листа стосовно платника податків від іншого органу державної влади, копія скарги від фізич- ної або юридичної особи на платника податку. Вищевказане доповнення пп. 73.3 Податкового кодексу України дасть можливість вирішити проблему неотримання Державною податковою службою України від платників податків відповідей на податкові запити через недотримання з боку уповноважених осіб Державної податкової служби України формальних вимог до таких податкових запитів.

Досконале регулювання правової природи податкових запитів дасть можливість Державній податковій службі України реалізувати функцію контролю повною мірою, отже, і ефект від такої реалізації буде більш впливовим, що $\epsilon$ позитивним явищем.

Висновки. Підбиваючи підсумки, можна зробити висновок, що податкові запити відграють важливу роль у виконанні функції контролю Державною податковою службою України. За допомогою податкових запитів Державна податкова служба України має змогу отримувати інформацію від платників податків, яка має суттєве значення для перевірки повноти надходження до бюджетів та державних цільових фондів податків, зборів, платежів, здійснення контролю за своєчасністю розрахунків в іноземній валюті в установлений законом строк, дотримання порядку проведення готівкових розрахунків за товари (послуги), проведення розрахункових операцій тощо. Чітке й оптимізоване регулювання правової природи податкових запитів $\epsilon$ дуже важливою складовою частиною реалізації функції контролю Державною податковою службою України. Водночас чинні законодавчо закріплені норми потребують удосконалення для більш ефективного виконання функцій, покладених на Державну податкову службу України.

\section{Література}

1. Конституція України від 28 червня 1996 р. № 254к/96. Відомості Верховної Ради України. 1996. № 30. C. 141.

2. Податковий кодекс України : Закон від 2 грудня 2010 р. № 2755-VI. Відомості Верховної Ради України. 2011. № № 13-17. С. 112.

3. Про затвердження положень про Державну податкову службу України та Державну митну службу України : постанова Кабінету Міністрів України від 6 березня 2019 р. № 227. Офіційний вісник України. 2019. № 26. С. 10.

4. Про затвердження Порядку періодичного подання інформації органам державної податкової служби та отримання інформації зазначеними орга- 
нами за письмовим запитом : постанова Кабінету

Денисова А. В., Міністрів України від 12 грудня 2010 р. № 1245. Офіційний вісник України. 2011. № 1. С. 103.

5. Гусак Н.Б., Гусак Ю.Д. Контроль податкових органів за діяльністю підприємств : навчальний посібник. Київ : Центр учбової літератури, 2007. С. 320.

6. Дозорець П.М. Контроль за сплатою податків та інших обов'язкових платежів - пріоритетний напрям діяльності органів державної фіскальної служби України. Науковий вісник Херсонського державного університету. 2015. Вип. 5. Т. 2. С. 117-120.

доктор юридичних наук, доцент, завідувач кафедри адміністративного права та адміністративного процесу одеського державного університету внутрішніх справ

Слаблюк Н. С., аспірант кафедри адміністративного права та адміністративного процесу Одеського державного університету внутрішніх справ 